\title{
4.0 Technology Within Fashion and Luxury Production*
}

\author{
Fabrizio Mosca**, Emily La Rosa ${ }^{* * *}$
}

\begin{abstract}
This paper investigates the implementation of Industry 4.0 systems within the production of fashion luxury goods, drawn by collecting the opinion of managers and perceptions of potential customers. 4.0 technologies can be applied in luxury fashion manufacturing without affecting the quality of the finished product yet customers are negatively inclined towards these technologies. Given the present situation of the fashion industry, which is now more demanding than ever, it would be consequently appropriate to implement these systems without disclosing them to customers.
\end{abstract}

Keywords: Luxury Goods; Production; Industry 4.0; Innovation; Fashion; Technology; Global Competition

\section{Industry 4.0 and Luxury}

Given the current research, we aim to demonstrate that in the world of luxury fashion production, there is room, if not the need, to implement Industry 4.0 technologies but to do so without affecting the quality of the final product. Companies in the fashion and luxury industries are characterised by a dynamic balance between supply and demand; global competition (Brondoni \& Arrigo, 2015); reduced entry barriers mainly represented by intangible factors; unstable and fast-changing demand; globalised value chains; high profitability; and the importance of the company's country of origin (Mosca, 2008).

We believe it is crucial that the luxury environment starts to seriously consider Industry 4.0 technologies because in recent years, the fashion industry has become ever more challenging.

As luxury items have become more accessible to the masses, customers are no longer content with simply obtaining the product; they often desire it before the general public has it, or want it fully customised in order to distinguish themselves from others. This implies a reduction of production times together with multiple rearrangements of the entire production process.

The concept of Industry 4.0 started with the exponential involvement of technological means during the production processes. The term describes the 'smart' factory model of the future where computer-driven systems 'monitor

\footnotetext{
* The Authors: Mosca, F. $\S \S 1,3,5$, La Rosa, E. §§ 2, 4

** Associate Professor of Management, University of Turin (fabrizio.mosca@ unito.it)

**** Press Celebrities \& VICs MRTW Product Manager, Louis Vuitton (emily.m.larosa@gmail.com)
} 
physical processes, create a virtual copy of the physical world and make decentralised decisions' based on self-organisation mechanisms (Smith, 2016).

The goal of Industry 4.0 is to reach a deeper interconnection and cooperation between the available resources and the final customer; it is a multiple layer arrangement composed of complex machines, people, products, and information within the production area and all along the value chain.

The implementation of these systems allows a company to achieve better levels of efficiency and can increase its competitive advantage; indeed, it is a revolution that involves a company at all levels, from the production centres to human resources (Paschetto, 2015).

Technologically, the approach is based on the introduction of Cyber-Physical Systems (CPS), which are collaborating computational entities that have intense connections with the surrounding physical world and its ongoing processes, providing and using the data-accessing and data-processing services available on the Internet (Fornari et al., 2018).

Although luxury fashion is quite a peculiar industry, all its processes are still very much cyclical and could benefit from the help of such implementations. Here, the main technologies that are often quoted as being at the core of Industry 4.0 are the Internet of Things (IoT), Big Data, additive manufacturing, 3D printing, augmented reality (AR) and new-generation robots (Beverer et al., 2015), all of which may seem too futuristic for an industry that has always been associated with craftsmanship.

When defining luxury, one of the qualities attributed to the products is the 'strong connection with the past proven by the tradition handed down over time' (Dubois, 2001), a description that can be taken quite literally as the heritage of the brand being built upon the traditions passed on by the different artisans who crafted the product.

However, as stated previously, if we divide the production process and analyse it in depth we find it to be cyclical, hence some of its phases may benefit from technologies that would make it trimmer without affecting the quality of the end product.

$\square$ An example of this can be seen with the laser-cutting
machines used for leather products. In just a few minutes a robot
can cut all the pieces required to create a handbag, yet it would
take up to half an hour if cut by hand. Even if mechanically
prepared, the bag will still need to be assembled by a highly
skilled artisan to become the exceptional quality product that
customers expect to see in stores.

Still, many are afraid that technological implementations will lead to the disappearance of the artisanal component, failing to understand that Industry 4.0 is not about complete automation but rather about human-machine interaction. Here, when talking about production, we will refer to the process in its entirety, from the sketches to the products in the stores. 


\section{Research Approach}

The current research was conducted using semi-structured interviews to survey professionals who work in different stages of luxury fashion production and who work for different companies. All the interviewees were chosen from the industry's biggest players: LVMH, Kering, Richemont, Hermès, Chanel and so on. To establish the sample of interviewees, we divided the production process into four main phases and then identified at least one professional to interview for each phase.

The subdivision applied was the following:

Phase 1 - Conception and Design

Phase 2 - Production and Merchandising

Phase 3 - Buying and Retail

Phase 4 - Supply Chain and Distribution.

Each interviewee was asked a set of specific questions related to the complexities of their job and the problems encountered while working. Among the sample, there were two professionals who did not belong to the production process but whom we deemed necessary in order to have a more complete overview of the process. One is a professor of fashion design at the Polytechnic University of Milan, and the other is a strategic planning analyst who works for Lectra, one of the biggest companies which produces technologies for the fashion world.

To investigate customer perceptions, we distributed a multiple-choice questionnaire to a heterogeneous sample of 200 people. Among the questions asked, one was strictly related to the use of technology, while the others covered the issues related to the use of technology that emerged while interviewing these professionals.

Despite not being directly on the use of technology itself, we judged the other questions important to evaluate if the problems emerging from the interviews were also relevant from the customer's point of view. The questions presented were the following:

1) How interested are you in luxury goods? (On a scale of 1 to 4 with: $1=$ low interest, $4=$ high interest)

2) How much is it worth to you to be able to buy a luxury item before it is on sale in stores? $(1=$ not much, $4=$ very much $)$

3) Would you think a handbag is of a better quality when it is completely handcrafted rather than the very same handbag produced by using some form of industrial processes?

4) Would you attribute a greater value to a luxury product if it were environmentally friendly?

The methodology used was successful in helping us understand management opinions and customer perceptions. Moreover, through the interviews (Table 1), we 
were able to highlight practical daily problems encountered by people who were directly involved in the production process.

Table 1: Interviews

\begin{tabular}{|c|c|c|c|}
\hline $\begin{array}{l}\text { 1) CREATION \& } \\
\text { DESIGN }\end{array}$ & $\begin{array}{l}\text { 2) PRODUCTION \& } \\
\text { MERCHANDISING }\end{array}$ & $\begin{array}{l}\text { 3) RETAIL \& } \\
\text { MARKETING }\end{array}$ & $\begin{array}{l}\text { 4) SUPPLY CHAIN } \\
\text { \& DISTRIBUTION }\end{array}$ \\
\hline $\begin{array}{l}\text { Interviewee \#1: } \\
\text { Freelance Fashion } \\
\text { Designer } \\
\text { Interviewee \#2: } \\
\text { Men's Footwear } \\
\text { Designer, Bottega } \\
\text { Veneta } \\
\text { Interviewee \#3, } \\
\text { Design Team } \\
\text { Assistant, Gucci } \\
\text { Interviewee \#4, } \\
\text { Senior Designer, } \\
\text { Louis Vuitton } \\
\text { Interviewee \#5, } \\
\text { Design Team Assistant } \\
\text { for silk accessories, } \\
\text { Gucci }\end{array}$ & $\begin{array}{l}\text { Interviewee \#6, } \\
\text { Product Development } \\
\text { Assistant, Givenchy } \\
\text { Interviewee \#7, } \\
\text { Assistant/Coordinator } \\
\text { for Kidswear \& } \\
\text { Beachwear, Missoni } \\
\text { Interviewee \#8, } \\
\text { Assistant Collection } \\
\text { Merchandiser, } \\
\text { Givenchy } \\
\text { Interviewee \#9, Shoes } \\
\text { Marketing Product } \\
\text { Manager, Chloé \& } \\
\text { See by Chloé } \\
\text { Interviewee \#10, } \\
\text { Assistant Collection } \\
\text { Merchandiser Woman } \\
\text { RTW, Hermès } \\
\text { Interviewee \#11, } \\
\text { Shoes Development } \\
\text { Assistant, Balenciaga } \\
\text { Interviewee \#12, } \\
\text { Junior Product } \\
\text { Manager Maille et } \\
\text { Twillaines, Hermès } \\
\text { Interviewee \#13, } \\
\text { Head of Woman RTW } \\
\text { Collections, Hermès }\end{array}$ & $\begin{array}{l}\text { Interviewee \#14, } \\
\text { Wholesale Area } \\
\text { Manager Assistant, } \\
\text { Christian Dior } \\
\text { Interviewee \#15, } \\
\text { Fashion Commercial } \\
\text { Coordinator for } \\
\text { Middle East and } \\
\text { India, Chanel } \\
\text { Interviewee \#16, } \\
\text { Marketing Assistant, } \\
\text { Miu Miu }\end{array}$ & $\begin{array}{l}\text { Interviewee \#17, } \\
\text { Distribution \& } \\
\text { Demand Sizing } \\
\text { Planner, Louis } \\
\text { Vuitton } \\
\text { Interviewee \#18, } \\
\text { Procurement Manager } \\
\text { Retail, Loro Piana }\end{array}$ \\
\hline
\end{tabular}

Source: Authors' interviews to companies' management $(2018,2019)$

\section{The Potential Implementation of Industry 4.0 Technologies in Luxury}

The objective was to prove that the implementation of Industry 4.0 technologies was both feasible and necessary. The following section will elaborate the results obtained from the interviews.

Because multiple issues emerged within the production process, we decided to use these as levers to advocate the potential implementations of Industry 4.0 technologies.

Fashion production has certain 'standard' steps or tasks in which issues might occur, so we focused on five points that currently challenge production and could be seized as opportunities for the implementation of specific technologies. We will also look at three limits that this kind of implementation may encounter. 


\subsection{Production Timings}

One of the main challenges in fashion has always been time; the rush to showcase a collection within a specific timeframe is a recurring problem. Industry 4.0 could help greatly, as well as address this issue in many phases.

The first implementation of Industry 4.0 technology could be in phase one, when the garments patterns are sketched. Designing these sketches on the computer and then using programs such as Modaris 3D to produce the patterns would allow a greater amount of them to be digitally stored and this could potentially speed up the development of future collections. In fact, even if collections change constantly, there are models that are permanent, especially in pre collections. Having a digital archive with the patterns ready to be sent to the supplier could save a great deal of time and money and would avoid the development of incorrect prototypes.

When launching new products, programs such as Modaris 3D could be employed to obtain a three dimensional visualisation of the design. Developed by Lectra, this software enables digitally drawn 2D patterns, and transforms them into 3D objects useful to visualise the volumes, as an initial step, and/or as a midway check-up during the development of the prototype.

Some designers exploit software such as Illustrator to digitally draw fashion sketches, and some fashion houses have already implemented Modaris 3D as the main pattern-making system. Despite limited cases, many companies still use traditional methods.

It is important to understand where these programs are useful and where they may negatively impact the process by slowing it down. Sometimes, creating a digital simulation of all the items to produce, although helpful in reducing mistakes, may take too much time. Nevertheless, potential solutions to address production timing issues can be implemented in phase two as well.

Many technologies are currently available, such as laser-cutting machines or smart interactive robots, which could help artisans develop products by speeding up processes and helping reduce costs. In addition, when it comes to benefitting from technology to reduce production times, one interviewee pointed out that having a program or a machine that helps the artisan save time while cutting the pieces allows him or her to have more time to assemble the product. All the extra time that is gained in this manner allows the brand to release a more refined product where each detail is meticulously crafted. Moreover, using these machines or robots would readily allow the use of pre-cut components to be assembled, leading to greater work flexibility.

\subsection{Forgery}

Another good reason to implement Industry 4.0 technologies is the opportunity to reduce forgeries.

Since online sales have boomed, there have been more and more cases of forgery every year. For some people, counterfeits are the only way to access their dream objects. Yet imitation does not necessarily imply the cloning of goods or illegal counterfeits. In fact, these imitations can be legal and very positive for a firm's development (Brondoni, 2012). In global markets, consumers identify different 
categories of imitations: product pirates, counterfeits, clones or knockoffs; design copies; creative adaptations; technological leapfrogging; and adaptation to other industries (Schnaars, 1994).

The vast majority of people who buy fakes are young adults between the ages of 25 and 35. Although the expensive price of the original may not be the main reason, it is what often leads consumers to buy the fake product. Trying to understand whether a product is original or not is possible, but not an easy task. Besides the most evident signs, such as the logo and the existence of said product on the market, there are elements that may help to identify fakes. Quite often, counterfeiters can be spotted by looking at the way the products are stitched or the material they are composed of. One interviewee explained that there are specific parts of a Louis Vuitton bag that will always use a very specific cut and type of leather. Although people working for the brands should always be able to recognise counterfeits, a quick and easy way to spot fakes would be to put a digital label chip in the bag.

Nowadays, some brands have started using Radio Frequency Identification (RFID) and Near-field Communication (NFC) systems, which are special chips placed on products that work as digital labels to track their movements. The only problem is that rather than being active chips, they are passive ones. This means that they cannot be tracked unless someone physically scans the products. In other words, although chipped, these products do not emit a GPS signal, so they cannot be traced in the cases of complete loss or robbery.

When dealing with such issues, with its IoT systems, Industry 4.0 could provide the perfect solution. In fact, because interconnected objects are provided with GPS, the products could be tracked and located at any given time. Moreover, because this kind of technology has already been developed for luggage, it would not be impossible to extend its use to luxury products. The only problem, as always with these types of solutions, is represented by the implementation costs.

\subsection{Environmental Cause}

The need for environmental protection was an issue that emerged in several of the interviews: 'Fashion and luxury companies have reinforced their corporate sustainability values and spread awareness among external stakeholders to defend their brands from the accusation of damaging the ecological and social environment' (Arrigo, 2015). 'Industry 4.0 holds a great opportunity for realising sustainable industrial value creation on all three sustainability dimensions: economic, social and environmental' (Stock et al., 2016). More robust progress has been made in the area of sustainability where new textile technologies and IT helped to increase the efficiency of clothing production. Here the development of innovative, smart materials and bio-materials contributed to the greening of the clothing industry. Driven by the fact that the fashion industry is the second biggest polluting industry, there was an urgent need for more sustainable fibres and a closed loop system (Bertola and Teunissen, 2018). What is more, we have often found polar opposite opinions, especially when it comes to fashion. The extremes range from people who, being vegan and strong PETA supporters, purchase only from Stella McCartney (who was one of the very first designers to launch a hit bag 
made of artificial leather), to people who can happily live surrounded by Fendi furs. But people are now becoming increasingly aware of the environmental impacts of products thanks to the easy access to information. For this reason, many enterprises are currently conducting research and development to produce leather in laboratories, and there is increased attention towards the more 'unfriendly' processes such as tanning.

Other than providing solutions to keep pollution under control, Industry 4.0 could help by using machines that prevent waste as much as possible. Currently, there is the possibility of using programs such Diamino, which lays out a pattern for cutting material in the most effective and efficient manner possible, cutting costs and at the same time being greener.

Another way Industry 4.0 technologies could be put to a more environmentally friendly use, is with 3D-printed prototypes. Of course, this would have to be largely evaluated depending on the product being prototyped because in some cases it is important to physically feel the garment. Having the possibility to touch the fabric to understand what it feels like, rather than having just a rough idea of it, is still crucial when a fashion collection is being developed; this is the reason why, in the interviewee's opinion, augmented reality in fashion works only up to a certain extent.

Given that 3D printing can be realised with recyclable polymers, in the case of mistakes or unfitted results, these 3D-printed products could be recycled, saving brands from having to pile up leather prototypes that are of no use and that cannot be commercialised. This solution would also avoid having to burn the products to destroy them.

\subsection{Internal Communication}

One of the first problems that emerged in the interviews and recurred multiple times was related communication. This is an issue because even when the information is collected, it is stored and exchanged using different programs and systems that may be incompatible. When it comes to product development, different types of software can be employed to coordinate the work along the value chain. The most popular, which is currently being implemented in many fashion houses, is Product Life Management (PLM). This program has proven to be extremely effective because it monitors the stages of production, providing information such as materials, Stock Keeping Units (SKUs), costs and much more. However, PLM is not very friendly in terms of its interface and usage, so many people dislike it. Moreover, PLM can be too expensive for smaller brands. In the fashion industry, it is generally complemented by another software system that allows the physical launch of production. Although these kinds of software enable good real-time updates, when it comes to production development, there is still a lot to improve on because they take a lot of time to update. Yet, in fashion last minute production changes may often occur, such as references eliminated just before the fashion show or cancelled following its low demand. Having systems that are sufficiently agile to keep up with these fluctuating rhythms is required.

Industry 4.0 could lead to future production implementation, especially thanks to digital manufacturing systems that would allow real-time control over production 
by increasing the levels of communication in the value chain at all steps. In fact, an interviewee mentioned that even if enacting digital manufacturing is quite difficult and would take a lot of time, it is not an unrealistic goal.

\subsection{Demand Forecast}

Another improvement that Industry 4.0 could bring to fashion production is the application of Big Data to forecast demand. Today, the constant unpredictable changes in fashion heavily affect demand which already has few reference standards. When it comes to forecasting, several factors can be an influence: trends, social media, consumption, habits and so forth.

The most volatile of these factors is social media because clients may cause a peak in demand after seeing a celebrity or an influencer wearing a specific item. It is evident that the more variables we consider when providing forecasts, the better the chances are of visualising a scenario that is closer to reality.

Because current forecasts are still computed by humans, it is hard to factor in all of these variables. In this situation, Big Data can have a positive impact, helping in collecting and factoring in multiple variables. Big Data is not a stranger to fashion, but was initially discarded by the larger companies and only used by less exclusive brands. The recent developments of an IoT framework and the advent of sensing technology have created a unified information grid that tightly connects systems and humans together, and this further populates a Big Data environment in the industry. Future industry will be able to achieve a fleet-wide information system that helps machines to be self-aware and actively prevents potential performance issues (Lee et al., 2014). Some fast fashion brands, such as La Redoute and Kiabi, are already availing themselves of Big Data and have employed people who simply take care of data collection and analysis.

Luxury fashion brands, which do not have the need to 'survive' in the fashion environment because they are already famous, initially did not pay much attention to Big Data but are now becoming more and more involved in this sphere.

In fact, the ability to consider and further develop existing information is what has now opened the door to new commercial scenarios such as Omnichannel platforms. More recent studies on this topic have considered the most widespread type, which is defined by the expression 'adding web to store', here relating to the development of the new online channel by retailers who are already operating in store-based channels (Deleersnyder et al., 2002; Biyalogorsky and Naik, 2003; Lee and Grewal, 2004; Weltevreden, 2007).

\section{The Main Limits to Technology Implementation in Luxury Industries}

Costs. Some limits can be identified for the implementation of 4.0 technologies in luxury industries. When talking about new technologies, the first limit relates to costs. With costs, we need to consider the specific required technologies, including those that are needed to make the implementation possible. Technology in general is expensive, and in a certain way, is a luxury in itself, something that is often just for a few elite companies. Clearly the burden of these costs changes according to 
the size of the brand. For instance, implementing PLM in some areas of the value chain requires hundreds of thousands of euros, which may represent a large part of smaller brand revenues. When pondering the implementation of these technologies, it is crucial to consider the cost opportunity: although the purchase cost is high, the amount of time and materials saved can be even higher.

For instance, developing prototypes for a fashion show can cost thousands of euros for each item, therefore, getting these prototypes right on the first try could help save a large amount of money.

Client perception and adverse attitude. The first limit of Industry 4.0 within the luxury industry is that clients, knowing that the product has been realised with the help of technological means, may perceive it as being of inferior quality. Customers are increasingly interested not only in tangible and intangible attributes of goods and services (Mosca, 2018), but also in a consistent and authentic narrative of the context (Bellini et. Al., 2018), the people and the process they relate to (Pine and Gilmore, 2007). We wanted to see whether this was just a myth in the minds of producers or if it was something that really occurs. Through the survey, we found that there is a bias from the consumer's side towards products created with the help of technology. However, when conducting the survey, the participants were in front of a screen, not in front of the real products. If a 'blind' test had been conducted presenting two products of which one was completely handcrafted and the other one realised by an artisan who used some technology, it is possible that it would be extremely difficult to tell the difference between the two. What makes this bias so strong is that there is a lack of knowledge regarding the manufacturing processes, resulting in people believing that technology lowers the quality of the product.

This, however, is a prejudice that could be easily countered by explaining, if necessary, where technology was implemented and how it positively affected the final outcome. A clear example of a sudden change of mind was given by one designer we interviewed who explained that although being extremely sceptical towards laser-cutting machines, he changed his mind once he saw how they worked and the quality of the results. We believe this attitude could be transferred to customers as well. One possible solution for 'technological education' could be videos that are placed inside stores, showing the production processes where both the machines and artisans are working together.

Clients are not simply biased towards technology, in fact, during the interviews, technology was often regarded as the enemy because the level of consumer satisfaction depends on the originality of the experience and the commitment of the individual. Further work has focused on the impact of new technologies, referencing a variety of devices, for example, mobile and alternative representations of the digital content, such as Augmented Reality (AR) versus Virtual Reality (VR) (Nasr et al., 2017; Buonincontri and Marasco, 2017; Evrard and Kreps, 2017; Petr and N'Gary, 2014; Pallud and Monod, 2010; Chang et al., 2014; Tost and Economou, 2009).

The adverse attitude towards technology comes from fear. Employees fear that technology will replace them. But the luxury fashion environment is a segment in which the artisanal component will never disappear because it is a key aspect of the products. One interviewee rightfully said that the attitude towards change depends 
mainly on how you decide to implement it and carry it on. So introducing technology step by step, hence avoiding panic, could be the best way to make employees accept technology and would give them time to become acquainted with the new processes.

Training of employees. Another big challenge in the implementation of Industry 4.0 systems is training employees. Luxury fashion production is an environment that requires the work of highly skilled artisans who have mastered the craft after many years of experience. It is precisely this experience that allows them to produce unique items, but this is also the reason why their average age is much older. This means that when it comes to training some of the employees which have never used computer software, they may have to be trained as if beginning a new profession. As one interviewee explained, 'People are reluctant to change and often refuse it', so starting all over again is something that depends heavily on the attitude of the individual. Currently, the problem is that the difference among the ages of the people working in the industry is extremely marked.

This generational gap may create situations such as people working on the same team but at two different speeds, where the older individuals transmit their craftsmanship and the technical information to the younger ones who, more prone to technology, will update the systems with the information received.

It is likely that when the generational turnover brings in only Millennials, who have grown up with the Internet and available technologies, the situation will change in a significant manner.

\section{An Original Approach for Implementing Technologies 4.0 in Luxury}

The survey ended up highlighting that customers have a negative attitude towards the use of new technologies within the production of luxury goods. In fact, they attribute a higher value to completely handcrafted products, not considering the possibility that the latter may have more defects.

The current research conducted showed that there are areas in which Industry 4.0 technologies could be implemented in luxury fashion production. These opportunities may be a solution to the problems that are currently encountered within the fashion domain. Some of these opportunities are actual needs, especially when it comes to production timings and internal communication.

The present research has also highlighted the complexities of introducing such technologies, one of the first limits being the high cost that certain Industry 4.0 implementations would require.

Even though we have indicated that there is a need, the main drawback is represented by the high costs of the implementation and by biases towards technology that many, especially the end customers, hold. We came to the conclusion that it would be best to avoid disclosing the use of such technologies to customers, who may perceive the product as having an inferior quality because technology was used in its creation.

The results of the current study can be considered encouraging. Even if one of the main problems highlighted is the negative attitude towards technology, introducing 
Industry 4.0 technology would require hiring people who can apply it properly, thus leading to the creation of new jobs. As previously pointed out, for those who are generally older individuals already in the field, it would be complicated to deal with such software and machines because it would require them to almost relearn their professions. It would be easier to hire and train new personnel.

Particular attention would need to be paid to customers, who may not be able to understand that the end product will remain the same when created with the help of technology. They might perceive the use of technology as a lack of authenticity and may end up feeling deprived of the product's exclusivity. Although this is not true, it is actually the opposite: it would help provide even better customisation services.

Given these reasons, it is important to keep clients focused on the artisanal component to keep the aura of the product untouched. The research started with the hypothesis that the luxury fashion world, which relies heavily on craftsmanship, can also employ some of the technological innovations taken from Industry 4.0, which are becoming, in some cases, necessary.

The present study, which interviewed professionals in the industry, led us to analyse the issues within the four main phases of the production process: conception and design, production and merchandising, buying and retail, and the supply chain and distribution. The problems arising from the analysis were shown to be solvable by making use of some Industry 4.0 systems.

The main issues highlighted, which could be used as a tactic to introduce these systems, relate to communication, demand forecast, environment, production timings and forgery. On the other hand, the potential limits of technological implementations were represented by their costs, the negative attitude towards them, from both clients and producers, and the relevant training that should be provided to employees. Nonetheless, the fact that these limits can be overcome, lead us to conclude that there is room to put these systems into practise within luxury fashion production.

Currently, enterprises are being pushed to always be more competitive. Luxury brands rely on, for the most part, a strong brand history highlighting craftsmanship; nevertheless, there is room to adapt to the upcoming technological changes.

Technology represents a potential solution that can allow the industry to remain competitive while maintaining their aura of exclusivity and elitism. Technology would not affect the quality of the end product, nor would it make it any less exclusive because the process of creating luxury products will always include some form of manual production.

One issue that would have to be carefully considered when implementing new technologies is security and, more specifically, cyber security. This has become an increasingly relevant topic in recent years and could potentially become one of the key issues for the enterprises that develop their business using Industry 4.0 systems.

New instruments, such as Big Data, are no longer only the collection of information concerning companies; they are also handling a great quantity of consumer sensitive data, so it becomes crucial to implement regular software solutions to protect all the information these companies hold.

In conclusion, what makes the luxury fashion industry so special is that the human component will always be the engine that keeps it going, no matter what machines can do. The implementation of technology can complement the industry 
without overwhelming craftsmanship, which will always have such a relevant weight that even with access and use of confidential information, this information will be governed by the need to make these items.

\section{Bibliography}

Bellini, N., Bergamasco, M., Brehnnet, R., Carrozzino, M., \& Lagier, J. (2018). Virtual Cultural Experiences: The Drivers of Satisfaction. Symphonya. Emerging Issues in Management (symphonya.unimib.it), (2), 52-65.

http://dx.doi.org/10.4468/2018.2.5bellini.bergamasco.brehonnet.carozzino.lagier

Beyerer, J., Jasperneite, J. \& Sauer, O. (2015). Industrie 4.0. at - Automatisierungstechnik 2015, 63(10), 751-752.

http://dx.doi.org/10.1515/auto-2015-0068

Bertola, P., \& Teunissen J. (2018). Fashion 4.0. Innovating Fashion Industry Through Digital Transformation. Research Journal of Textile and Apparel, 22(4), 352-369.

http://dx.doi.org/10.1108/RJTA-03-2018-0023

Biyalogorsky, E., \& Naik, P. (2003). Clicks and Mortar: the Effect of Online Activities on Offline Sales. Marketing Letters, (14), 21-32.

http://dx.doi.org/10.1023/A:1022854017292

Brondoni, S. M. (2012). Innovation and Imitation: Corporate Strategies for Global Competition. Symphonya. Emerging Issues in Management (symphonya.unimib.it), (1), 10-24.

http://dx.doi.org/10.4468/2012.1.02brondoni

Brondoni, S. M., \& Arrigo, E. (2015). Overture de 'Fashion and Luxury Management'. Symphonya. Emerging Issues in Management (symphonya.unimib.it), (4), 1-8.

http://dx.doi.org/10.4468/2015.4.01ouverture

Buonincontri, P., \& Marasco, A. (2017). Enhancing Cultural Heritage Experiences with Smart Technologies: An Integrated Experiential Framework. European Journal of Tourism Research, 17, 83-101.

Chang, K. E., Chang, C. T., Hou, H. T., Sung, Y. T., Chao, H. L., \& Lee, C. M. (2014). Development and Behavioral Pattern Analysis of a Mobile Guide System with Augmented Reality for Painting Appreciation Instruction in an Art Museum. Computers \& Education, 71, 185-197.

http://dx.doi.org/10.1016/j.compedu.2013.09.022

Deleersnyder, B., Geyskens, I., Gielens, K., \& Dekimpe, M. G. (2002). How Cannibalistic Is the Internet Channel? A Study of the Newspaper Industry in the United Kingdom and the Netherlands. International Journal of Research in Marketing, 19(4), 337-348.

http://dx.doi.org/10.1016/S0167-8116(02)00099-X

Dubois, B., Laurent, G., \& Czellar, S. (2001). Consumer Rapport to Luxury: Analysing Complex and Ambivalent Attitudes (No. 736). HEC Paris.

Evrard, Y., \& Krebs, A. (2017). The Authenticity of the Museum Experience in the Digital Age: the Case of the Louvre. Journal of Cultural Economics, 42(3), 353-363.

http://dx.doi.org/10.1007/s10824-017-9309-x

Fornari, D., Grandi, S., \& Fornari, E. (2018). Retailing 4.0: The New Era of E-commerce in Fast Moving Consumer Goods. Symphonya. Emerging Issues in Management (symphonya.unimib.it), (2), 77-90. http://dx.doi.org/10.4468/2018.2.07fornari.grandi.fornari

Lee, R. P., \& Grewal, R. (2004). Strategic Responses to New Technologies and Their Impact on Firm Performance. Journal of Marketing, 68(4), 157-171.

http://dx.doi.org/10.1509/jmkg.68.4.157.42730 
Lee, J., Kao, H., \& Yang, S. (2014). Service Innovation and Smart Analytics for Industry 4.0 and Big Data Environment. Procedia CIRP, 16, 3-8.

http://dx.doi.org/10.1016/j.procir.2014.02.001

Mosca, F. (2008). Market-Driven Management in Fashion and Luxury Industries. Symphonya. Emerging Issues in Management (symphonya.unimib.it), (1), 65-71.

http://dx.doi.org/10.4468/2008.1.06mosca

Mosca, F., \& Civera C. (2018). Digital Channels and Social Media Management in Luxury Markets. Turin: Giappichelli - Routledge.

Nasr, I. B., Hallem, Y., \& Lagier, J. (2017). Quel est le rôle de l'application mobile dans la valorisation de l'expérience muséale? Management \& Avenir, 2, 87-108.

http://dx.doi.org/10.3917/mav.092.0087

Pallud, J., \& Monod, E. (2010). User Experience of Museum Technologies: the Phenomenological Scales. European Journal of Information Systems, 19(5), 562-580.

http://dx.doi.org/10.1057/ejis.2010.37

Paschetto, E. (2015). Luxury Fashion versus a Fast-Fashion Environment. Symphonya. Emerging Issues in Management (symphonya.unimib.it), (4), 40-47.

http://dx.doi.org/10.4468/2015.4.05paschetto

Petr, C., \& N'Gary, E. (2014). L'œuvre vue à travers une tablette mobile: quid des comportements d'appropriation culturelle et des modes de reception artistique, in Dang Nguyen, G., \& Dejean, S. (eds), Internet: Interactions et Interface. Paris: L'Harmattan.

Pine, B. J., \& Gilmore, J. H. (2007). Authenticity, What Consumers really want, Cambridge, Boston: Harvard Business School Press.

Schnaars, S. P. (1994). Managing Imitation Strategy: How Later Entrants Seize Markets from Pioneers, New York: The Free Press.

Stock, T. \& Seliger, G. (2016). Opportunities of Sustainable Manufacturing in Industry 4.0, Procedia CIRP, 40, 536-541.

http://dx.doi.org/10.1016/j.procir.2016.01.129

Tost, L. P., \& Economou, M. (2009). Worth a thousand words? The usefulness of immersive virtual reality for learning in cultural heritage settings. International Journal of Architectural Computing, 7(1), 157-176.

http://dx.doi.org/10.1260/147807709788549367

Weltevreden, J. W. J. (2007). Substitution or Complementarity? How the Internet Changes City Centre Shopping. Journal of Retailing and Consumer Services, 14(3), 192-207.

http://dx.doi.org/10.1016/j.jretconser.2006.09.001

Zook, Z., \& Smith, P. R. (2016). Marketing Communications: Offline and Online Integration, Engagement and Analytics. London: Kogan Page Publishers. 